Журнал«Герстективита інновації наукиљ

(Серія «Гедагогіка», Серія«Гтихологія», Серія«Медицина»

№(6) 2022

УДК 37.091.33 -059

https://doi.org/10.52058/2786-4952 -2022-1(6)-26-33

Башкір Ольга Іванівна доктор педагогічних наук, доцент, професор кафедри освітології та інноваційної педагогіки, Харківський національний педагогічний університет імені Г.С. Сковороди, вул. Валентинівська, 2, м. Харків, 61168, тел.: (098) 446-82-62, https://orcid.org/0000-0001-5237-9778

\title{
ФОРМУВАННЯ SОFТ SKILLS ЗАСОБАМИ АКТИВНИХ ТА ІНТЕРАКТИВНИХ МЕТОДІВ РЕФЛЕКСІї
}

Анотація. У статті автором акцентовано увагу на важливості формування в здобувачів освіти soft skills, до яких належать зокрема і навички рефлексії, яка сприяє мотивації особистості до саморозвитку та самовдосконалення, виявленню ефективних шляхів та способів покрашення освітнього процесу, зокрема й за індивідуальною траєкторією розвитку особистості здобувача освіти. Виявлено класифікацію видів рефлексії як самоаналізу навчальної діяльності здобувачів освіти (рефлексія настрою та емоційного стану, рефлексія діяльності та рефлексія змісту навчального матеріалу) та запропоновано конкретні активні та інтерактивні методи, які доречно застосовувати для кожного виду.

Рефлексію настрою та емоційного стану доречно здійснювати активними методами навчання («Наклей настрій», «Три обличчя», «Комплімент-похвала» тощо) на початку заняття на загальному та індивідуальному рівнях. Загальний призначений для фронтальної роботи і має на меті поліпшити настрій за допомогою емоційно-художнього оформлення; індивідуальний рівень спрямований на виявлення настрою окремих здобувачів освіти. Ці методи носять активний характер і сприяють організації інтерактивної взаємодії на наступних етапах заняття чи освітньої взаємодії.

Рефлексію діяльності автором рекомендовано формувати активними та інтерактивними методами «Як ми працювали», «Як я працював/ла?», «Як я впорався/лася 3 конкретним завданням», «Східці успіху», «Рефлексійна мішень», «Світлофор», «Три М + Д» тощо. Ці методи дають можливість осмислити способи та прийоми роботи 3 навчальним матеріалом, знайти найефективніші та найраціональніші з них.

Рефлексія змісту навчального матеріалу сприяє виявленню продуктивності навчального заняття, рівня усвідомленості його змісту. Цей вид рефлексії доречно здійснювати за допомогою методів активного та інтерактивного навчання «Незакінчене речення», «Плюс-мінус-цікаво», «Корисно-некорисно-знадобиться», «М'ясорубка», «Шість капелюхів мислення», синквейн.

Ключові слова: рефлексія, методи, навчання, активний, інтерактивний. 
Bashkir Olha Ivanivna Doctor of Pedagogy, associate professor, professor at the Chair of Educology and Innovative Pedagogy H.S. Skovoroda Kharkiv National Pedagogical University, Kharkiv, 61168, Valentynivska St., 2, https://orcid.org/0000-0001-5237-9778

\title{
FORMATION OF SOFT SKILLS BY MEANS OF ACTIVE AND INTERACTIVE REFLECTION METHODS
}

\begin{abstract}
In the article, the author focuses on the importance of developing soft skills among applicants for education, which include, among other things, reflection skills that help motivate the individual to self-development and selfimprovement, identifying effective ways and means of decorating the educational process, including along the individual trajectory of personality development applicant for education. A classification of the types of reflection as self-analysis of the educational activity of applicants for education (reflection of mood and emotional state, reflection of activity and reflection of the content of educational material) is revealed, and specific active and interactive methods are proposed that are appropriate to apply for each type.

It is appropriate to carry out reflection of mood and emotional state by active teaching methods («Stick the mood», «Three faces», «Compliment-praise», etc.) at the beginning of the lesson at the general and individual levels. The general one is intended for frontal work and aims to improve the mood with the help of emotional and artistic design; the individual level is aimed at identifying the mood of individual applicants for education. These methods are active and contribute to the organization of interactive interaction at the subsequent stages of a lesson or educational interaction.

The author recommends to form the reflection of activity by active and interactive methods «How did we work?», «How did I work?», «How did I cope with a specific task?», «Steps of success», «Reflexive target», «Traffic light», «Three $M+D »$, etc. These methods make it possible to comprehend the methods and techniques of working with educational material, to find the most effective and rational of them.

Reflection of the content of the educational material helps to identify the productivity of the lesson, the level of awareness of its content. It is appropriate to carry out this type of reflection with the help of active and interactive learning methods «Unfinished sentence», «Plus-minus-interesting», «Useful, useless, needed», «Meat grinder», «Six thinking hats», cinquain.
\end{abstract}

Keywords: reflection, methods, learning, active, interactive.

Постановка проблеми. В умовах сучасного глобалізованого суспільства та викликів дистанційної освіти все більше уваги приділяється становленню і всебічному розвиткові особистості, здатної активно проявляти себе в непередбачених обставинах, вирішувати проблемні ситуації, домовлятися, 
піддавати критиці шалені інформаційні дані та повідомлення, активно здійснювати самовдосконалення, піддаючись конструктивній самокритиці.

Активному саморозвиткові особистості сприяє їі здатність до рефлексії. Завдяки вмінню рефлексувати свою поведінку та вчинки інших людей, особа розвиває в собі такі soft skills, як проникливість, чуйність, терплячість, тактовність. Ці якості сприяють гармонізації відносин 3 людьми. Особистість часто вдається до рефлексії під час проблемної ситуації для успішного ї̈ вирішення.

Рефлексія є важливою під час індивідуальної роботи, спільної діяльності здобувачів освіти. Саме рефлексивний огляд усіх складників конкретного завдання та власних дій дозволяє людині, зайнявши іншу розумову позицію, відшукати потрібну ланку в конкретній ситуації або усвідомити власну помилку.

Аналіз останніх досліджень і публікацій. Питання організації рефлексії на заняттях здобувачів освіти порушуються як у психології, так і в педагогіці та методиках викладання освітніх дисциплін. Зокрема, теоретичні основи рефлексії як освітнього явища розглядають А. Бізяєва, Л. Богадьорова, К. Ковальова, М. Холодна, А. Хуторський, Л. Штефан. Особливості та способи організації рефлексії здобувачів освіти порушують О. Башкір, В. Борисов, В. Плахтєєва, Г. Процик, О. Ковтун, Г. Крапівник, Н. Сенчина, Н. Тучина та інші. Однак поза увагою дослідників залишається питання методів організації рефлексії та мало приділено уваги значенню рефлексії як soft skills здобувача освіти. Мета статті - узагальнити та проаналізувати активні та інтерактивні методи організації рефлексії як гнучкої навички (soft skills) здобувача освіти.

Виклад основного матеріалу. Слово «рефлексія» походить від латинського reflexio, що в перекладі означає «звернення назад», роздуми про свій внутрішній стан, самопізнання. У тлумачних словниках української мови термін «рефлексія» означає відсвічування, відблискування; самоаналіз, роздуми людини над власним душевним станом; у філософії - відображення, а також дослідження процесу пізнання [5, с.567].

К.І. Ковальова та Л.М. Богадьорова розглядають рефлексію як «здатність людини здійснювати будь-які дії або вчинки i при цьому фіксувати у свідомості кожну деталь, тобто одночасно бути «виконавцем» діï i iii «спостерігачем»» [4]. Використовуючи рефлексію в освітньому процесі, учителі вкладають у неї самоаналіз діяльності та їі результатів.

У педагогіці рефлексія трактується як процес усвідомлення чогось за допомогою вивчення i порівняння. У широкому практичному значенні рефлексія розглядається як здатність людини до самоаналізу, осмислення i переосмислення своїх предметно-соціальних ставлень до навколишнього світу. У комунікативних процесах рефлексія розуміється як процес відображення однією людиною внутрішнього світу іншої. Рефлексія дає можливість людині свідомо контролювати своє мислення як $з$ точки зору його змісту, так і його засобів [6]. 
Серед активних методів можна виокремити такі: «Мотивуй іншого», «Хто Я?», «Автопортрет», «Обмін», «Професійне Я» «У променях сонця», «Чотири фрази», «Я - емоція», «Він - емоція», «Несправедлива образа», «Чи легко правильно слухати?», «Відгадай», «Відчуй іншого», «Фантом», «Фотокартка», «Педагогічний експрес», «Постав себе на місце іншого», «Дерево мого Я», «Аналіз проблемної ситуації», «Важкий учень», «Рефлексивне коло запитань», case study, рефлексивні полілоги та інтерв’ю («Вибір конфліктної ситуації», «Урок»), «Рефлексивне коло», «Телеграма», «Анкета-газета», рефлексивні ігри («Знайди вихід», «Reflexive game»). Серед інтерактивних методів варто зазначити інтерактиви «Робота в парах», «Акваріум», «Мозкова атака», «Мікрофон», психодраматичний етюд («Монолог»), психотехнічні ігри i вправи («Тиск», «Відкритість», «Другий план», «Дзеркало», «Поведінка в конфлікті та його розв'язання») тощо [1; 5]. Вибір методу рефлексії залежить від етапу проведення заняття та цілей, яких потрібно досягти на конкретному занятті.

Перевіреним засобом рефлексії є питання. Однак викладачеві варто знати, що далеко не всі питання сприяють рефлексії. Порожні питання не сприяють думці та міркуванню. Питання без емоційного забарвлення також залишають здобувачів освіти байдужими. А надто важкі питання, без врахування реальних можливостей здобувачів освіти, а, крім того, час на їх обмірковування обмежений, відбивають будь яке бажання витрачати час на їх обмірковування.

Секрет «правильного» питання, яке б сприяло рефлексі, полягає в тому, що люди думатимуть над тими питаннями, у яких приховане щось, над чим хочеться думати. I це «щось» становить собою проблема. Однак представити перед здобувачами проблему, яку вони б хотіли розв'язати, - велике мистецтво, яке потребує від викладача знань вікових та особистісних якостей здобувачів, а також їхніх інтересів і вподобань [12].

У практиці рефлексивного навчання розроблено різні підходи проблематизації навчальної ситуації Ось деякі 3 них: •запропонувати здобувачам освіти придумати способи представлення інформації, альтернативні тому, що представлено в навчальній літературі або в поясненні викладача; •запропонувати здобувачам освіти порівняти різний виклад та інтерпретацію тих самих подій, ідей, явищ; •запропонувати здобувачам освіти вигадати альтернативні варіанти дозволу відомих подій із прогнозом відповідних наслідків; •запропонувати здобувачам освіти ігровий прийом «що було б, якщо...»; •запропонувати здобувачам освіти самостійно «додумати» будь-який феномен або подію, у поясненні якого викладач навмисно не згадав певні факти чи деталі тощо[3, с.54].

Великого значення рефлексія набуває під час мисленнєвих процесів. Поряд із когнітивними процесами переробки інформації (сприйняття, пам'ять, мислення) існують метакогнітивні процеси, які забезпечують організацію та регуляцію когнітивних. До таких належать інтегральні психічні процеси у вигляді цілепокладання, планування, прогнозування, прийняття рішення тощо. 
Інтелектуальна рефлексія, або рефлексія власної розумової діяльності, - це здатність усвідомлювати підгрунтя власного мислення.

Особливість рефлексії як структурної одиниці заняття полягає в тому, що іiі можуть здійснювати не тільки в кінці заняття, як було прийнято вважати раніше, а й на будь-якому його етапі [4]. Загальноприйнятою вважають таку класифікацію рефлексії, засновану на функціональних відмінностях:

- рефлексія настрою та емоційного стану;

- рефлексія діяльності;

- рефлексія змісту навчального матеріалу.

Рефлексію настрою та емочійного стану доцільно проводити на початку заняття 3 метою встановлення емоційного контакту з колективом, визначення готовності до роботи, тестування міжособистісних стосунків між класом та окремими здобувачами освіти. Рефлексія настрою дозволяє виявити в здобувачів освіти неробочий настрій, апатію, агресію та інші негативні прояви на загальному та індивідуальному рівнях. Загальний призначений для фронтальної роботи і має на меті поліпшити настрій за допомогою емоційнохудожнього оформлення. До цих методів належить перегляд картин, презентацій, музичний супровід, відео-фрагменти тощо) [2; 7].

Індивідуальний рівень спрямований на виявлення настрою окремих здобувачів осіти. Тут доречно просто попросити намалювати смайлик, що відображає настрій людини, можна використати прийоми «Наклей настрій», «Три обличчя». Наприкінці заняття доречно використати також прийом «Компліментпохвала», під час якого здобувачі освіти оцінюють внесок товаришів у заняття, дякують один одному та викладачеві за проведений спільно час.

Рефлексія діяльності дає можливість осмислити способи та прийоми роботи з навчальним матеріалом, знайти найефективніші та найраціональніші 3 них; передбачає дослідження діяльності, яка вже відбулася, з метою фіксації іiï результатів і підвищення в подальшому її ефективності [3, с. 49]. Вона може здійснюватися і на етапі перевірки домашнього завдання, і після проведення будь якого виду роботи, і під час підбиття підсумків заняття, і навіть цілого навчального року. Під час рефлексії здобувачі освіти мають дати відповіді на запитання «Як ми працювали», «Як я працював/ла?», «Як я впорався/лася 3 конкретним завданням» тощо. А. Хуторський [10] пропонує методику організації рефлексії на уроці:

1) зупинка предметної діяльності (діяльність, яка виконується з певного навчального предмета, має бути завершена або призупинена; уся увага здобувачів освіти зосереджується на аналізі проробленої роботи);

2) установлення послідовності дій (здобувачам освіти пропонується усно чи письмово прописати всі свої дії під час діяльності, що рефлексується);

3) аналіз відтвореної послідовності дій з точки зору іiі ефективності, продуктивності, відповідності поставленим завданням тощо (параметри для аналізу матеріалу, що рефлексується, пропонуються викладачем або визначаються самими здобувачами освіти на основі навчальних цілей); 
4) виявлення та формування результатів рефлексії (ідеї, припущення, відповіді тощо за змістом предметної діяльності; прийоми та способи дій, що використовувалися впродовж діяльності; гіпотези, прогнози стосовно організації подальшої діяльності, іï якісної та кількісної сторін);

5) перевірка гіпотез на практиці в подальшій предметній діяльності.

Застосування рефлексії діяльності наприкінці заняття дає можливість оцінити активність кожного на різних етапах уроку. У процесі змішаного навчання доречно використовувати прийоми «Східці успіху», «Рефлексійна мішень», «Світлофор», «Три М + Д» тощо [7].

Рефлексія змісту навчального матеріалу сприяє виявленню продуктивності навчального заняття, рівня усвідомленості його змісту. Класичним прийомом цього виду рефлексії $є$ «Незакінчене речення». Його можна записати на аркушах, на дошці, спроєктувати на екрані в режимі реального часу та онлайн. До незакінчених речень належать такі: сьогодні $я$ дізнався / дізналася..., було иікаво..., я виконував / виконувала завдання..., я зрозумів / зрозуміла, що..., тепер я можу..., я відчув / відчула, що..., я набув / набула..., я навчився / навчилася..., у мене вийшло..., я зміг / змогла.., я спробую..., мене здивувало..., урок дав мені для життя..., мені захотілося..., мене надихнуло...

Крім того, наприкінці навчального заняття можна використовувати метод «Плюс-мінус-цікаво», «Корисно-некорисно-знадобиться», «М'ясорубка», «Шість капелюхів мислення» тощо. Останній можна використовувати як усно, так і письмово. Він, на переконання Л. Штефан [11], передбачає вироблення автономних умінь під час рефлексії через виконання лише однієї розумової дії у певний час. При цьому кожній розумовій дії умовно відповідає якийсь колір капелюха мислення (усний метод). Здобувачам освіти пропонується заповнити таблицю 3 трьох стовпчиків-граф (письмовий метод). У графу «плюс» записують усе, що сподобалося на занятті (інформацію, форми роботи, прийоми, засоби тощо); у графу «мінус» записують усе, що не сподобалося, було нудним, викликало відразу, залишилося незрозумілим або є непотрібним для вирішення повсякденних життєвих ситуацій; графу «цікаво» здобувачі освіти заповнюють фактами, про які вперше дізналися на занятті, або що ще їм би хотілося почути в межах проблеми, що порушувалася [7].

Цікавим методом рефлексії змісту навчального матеріалу є дидактичний синквейн. Цей метод був уведений у практику американської школи в XX ст. під впливом японської поезії. Слово «синквейн» («сенкан») походить від французького слова «п’ять». Звідси витікає, що синквейн - це вірш, що містить п'ять неримованих рядків, побудованими за певними правилами. Цей метод сприяє вдумливій рефлексії, заснованій на багатому понятійному запасі.

Крім традиційного варіанту синквейна можна запропонувати такі варіації: складання короткого оповідання за готовим синквейном з використанням слів і фраз, які входять до його складу; корекція та вдосконалення синквейна; аналіз неповного синквейна без вказівки теми синквейна і визначення назви 
цього п'ятивірша; синквейн-загадка (без першого рядка - необхідно відгадати, яке поняття розглядатиметься, а впродовж заняття удосконалити його або створити власний синквейн). Рефлексію змісту навчального матеріалу доцільно здійснювати за допомогою і активних, i інтерактивних методів навчання.

Висновки. Отже, порушені автором питання формування soft skills засобами активних та інтерактивних методів рефлексії сприяли їхньому узагальненню та характеристиці. В освітньому процесі рефлексію доречно проводити не лише наприкінці заняття, а й на будь-якому його етапі. Звідси вирізняють рефлексію настрою та емоційного стану, рефлексію діяльності та рефлексію змісту навчального матеріалу. Переважно ці методи носять активний характер і сприяють організації інтерактивної взаємодії.

\section{Лimepamypa:}

1. Башкір О. I. Активні й інтерактивні методи навчання у вищій школі. Педагогіка та психологія : зб. наук. пращь. Харків : ТОВ «ДІСА ПЛЮС», 2018. Вип. 60. С. 33-45.

2. Башкір O.І. Сучасні методи та прийоми рефлексії. Психолого-педагогічні проблеми вищої $і$ середньої освіти в умовах сучасних викликів: теорія $і$ практика : матеріали V Міжнародної науково-практичної конференції (Харків, 31 березня - 2 квітня 2021 р.). У 2 томах. Харків : «Стиль-Издат», 2021. Т.2. С.28-31.

3. Бизяева А.А. Психология думающего учителя: педагогическая рефлексия. Псков: ПГПИ им. С. М. Кирова, 2004. 216 с.

4. Ковальова К.І. Богадьорова Л.М. Рефлексія як структурна одиниця уроку. Науковий вісник Херсонського державного університету. Серія: педагогічні науки. Херсон, 2018. Випуск № 82 С. 45-48.

5. Ковтун О., Сенчина Н. Зміст поетапного формування педагогічної рефлексії учителів гуманітарних спеціальностей у післядипломній освіті. Вісник Національного авіаційного університету. Серія: Педагогіка. Психологія: зб. наук. пр. 2019. Вип. 1 (14). С. 54-59.

6. Процик Г.М. Особливості використання рефлексії при вивченні іноземної мови. Матеріали IV Міжнародної науково-технічної конференції молодих учених та студентів. Актуальні задачі сучасних технологій. Тернопіль, 25-26 листопада 2015. С.230.

7. Садкіна В.І. Маленькі секрети учительського успіху. Навчаємо з радістю. Харків: Вид. група «Основа», 2016. 144c.

8. Тлумачний словник української мови / [укладачі Ковальова Т.В., Коврига Л.П.]. Харків : Синтекс, 2002. 672c.

9. Холодная М.А. Психология интеллекта. Парадоксы исследования: 2-ое изд., перераб. и доп. СПб.: Питер. 2002. 272c. URL: http://www.intellect-invest.org.ua/content/ userfiles/files/library/Holodnaya_Psihologiya_intellekta.pdf

10. Хуторской А.В. Современная дидактика: Учебник для вузов. СПб: Питер, 2001. 544c.

11. Штефан Л.В. Концепція латерального мислення Е. Боно як основа активізації творчої діяльності майбутніх інженерів-педагогів. Теорія і практика упр. сои. системами: філософія, психологія, педагогіка, соціологія : щокв. наук.-практ. журн. 2014. № 2. С. 27-33.

12. Krapivnyk G., Tuchyna N., Bashkir O., V. Borysov, Gonchar O., Plakhtyeyeva V. Modelling the Process of Reflection with Pre-Service Student Teachers. Revista Romaneasca Pentru Educatie Multidimensionala. 2021. 13(3). P.116-133. DOI: https://doi.org/10.18662/rrem/13.3/443

\section{References:}

1. Bashkir O. I. (2018). Aktyvni y interaktyvni metody navchannia u vyshchii shkoli [Active and interactive teaching methods in higher education]. Pedahohika ta psykholohiia : zb. nauk. prats. Kharkiv : TOV «DISA PLIuS», Vyp. 60. S. 33-45. 
2. Bashkir O.I. (2021). Suchasni metody ta pryiomy refleksii [Modern methods and techniques of reflection]. Psykholoho-pedahohichni problemy vyshchoi i serednoi osvity v umovakh suchasnykh vyklykiv: teoriia i praktyka : materialy V Mizhnarodnoi naukovo-praktychnoi konferentsii (Kharkiv, 31 bereznia - 2 kvitnia 2021 r.). U 2 tomakh. Kharkiv : «Styl-Yzdat». T.2. S.28-31.

3. Byziaeva A.A. (2004). Psykholohyia dumaiushcheho uchytelia: pedahohycheskaia refleksyia [Psychology of a Thinking Teacher: Pedagogical Reflection]. Pskov: PHPY ym. S. M. Kyrova. 216 s.

4. Kovalova K.I. Bohadorova L.M. (2018). Refleksiia yak strukturna odynytsia uroku [Reflection as a structural unit of the lesson]. Naukovyi visnyk Khersonskoho derzhavnoho universytetu. Seriia: pedahohichni nauky. Kherson. Vypusk № 82 S. 45-48.

5. Kovtun O., Senchyna N. (2019). Zmist poetapnoho formuvannia pedahohichnoi refleksii uchyteliv humanitarnykh spetsialnostei u pisliadyplomnii osviti [The content of the gradual formation of pedagogical reflection of teachers of humanities in postgraduate education]. Visnyk Natsionalnoho aviatsiinoho universytetu. Seriia: Pedahohika. Psykholohiia: zb. nauk. pr. Vyp. 1 (14). S. 54-59.

6. Protsyk H.M. (2015). Osoblyvosti vykorystannia refleksii pry vyvchenni inozemnoi movy [Features of the use of reflection in the study of a foreign language]. Materialy IV Mizhnarodnoi naukovo-tekhnichnoi konferentsii molodykh uchenykh ta studentiv. Aktualni zadachi suchasnykh tekhnolohii. Ternopil, 25-26 lystopada. S.230.

7. Sadkina V.I. (2016). Malenki sekrety uchytelskoho uspikhu [Little secrets of teacher success]. Navchaiemo z radistiu. Kharkiv: Vyd. hrupa «Osnova». 144s.

8. Tlumachnyi slovnyk ukrainskoi movy [Explanatory dictionary of the Ukrainian language]. (2002). / [ukladachi Kovalova T.V., Kovryha L.P.]. Kharkiv : Synteks. 672s.

9. Kholodnaia M.A. (2002). Psykholohyia yntellekta. Paradoksы yssledovanyia [The psychology of intelligence. Research paradoxes]: 2-oe yzd., pererab. y dop. SPb.: Pyter. 272s. URL: http://www.intellect-invest.org.ua/content/userfiles/files/library/Holodnaya_Psihologiya_intellekta.pdf

10. Khutorskoi A.V. (2001). Sovremennaia dydaktyka [Modern didactics]: Uchebnyk dlia vuzov. SPb: Pyter, 544s.

11. Shtefan L.V. (2014). Kontseptsiia lateralnoho myslennia E. Bono yak osnova aktyvizatsii tvorchoi diialnosti maibutnikh inzheneriv-pedahohiv [E. Bono's concept of lateral thinking as a basis for activating the creative activity of future engineers-teachers]. Teoriia $\mathrm{i}$ praktyka upr. sots. systemamy: filosofiia, psykholohiia, pedahohika, sotsiolohiia : shchokv. nauk.prakt. zhurn. № 2. S. 27-33.

12. Krapivnyk G., Tuchyna N., Bashkir O., V. Borysov, Gonchar O., Plakhtyeyeva V. (2021). Modelling the Process of Reflection with Pre-Service Student Teachers. Revista Romaneasca Pentru Educatie Multidimensionala. 13(3). P.116-133. DOI: https://doi.org/10.18662/rrem/13.3/443 